\begin{tabular}{|c|c|c|}
\hline & $\begin{array}{l}\text { International Journal of Environment, Agriculture and Biotechnology } \\
\text { Vol-6, Issue-1; Jan-Feb, } 2021\end{array}$ & 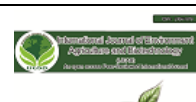 \\
\hline IJEAB & $\begin{array}{c}\text { Journal Home Page Available: } \text { https://ijeab.com/ } \\
\text { Journal DOI: } 10.22161 / \text { ijeab }\end{array}$ & \\
\hline
\end{tabular}

\title{
Determinants of Level of Accessibility to Microfinance among Loan beneficiaries of some Commercial Crop Production Farmers in Niger state, Nigeria
}

\author{
Mahmud H. U
}

Minna Niger State, Nigeria.

Received: 21 Nov 2020; Received in revised form: 14 Jan 2021; Accepted: 15 Feb 2021; Available online: 21 Feb 2021

(C)2021 The Author(s). Published by Infogain Publication. This is an open access article under the CC BY license

(https://creativecommons.org/licenses/by/4.0/).

\begin{abstract}
The study analyzed the determinants of some selected commercial crop farmers' accessibility to microfinance services in Niger state, Nigeria. Multistage random sampling technique was used in selecting respondents who were beneficiaries of Microfinance Institutions (MFIs) spread across the 3 agricultural zones in the state; from which primary data were collected using questionnaires. A total of 185 crop farmers who are beneficiaries of Microfinance Institutions (MFIs) were used in the study. Method of data analysis used was means, frequencies, percentages, and double hurdle analysis. The result revealed that gender, age, education, household size, income, farm size and farming experience are the socio-economic variables influencing commercial crop farmers' access to MFIs. The accessibility of microfinance to crop farmers was found to be determined by household and loan characteristic of the farmers. It showed that there was a significant difference in the total income, farm capital, land size, household size and education level between the two groups of farmers but no significant difference in their age, marital status, farming experience and output level. It was also found out that age, farm size, income, education and household size were factors that significantly affect access to credit. Equally, age, farm size, marital status, cost of loan, education level and farming experience was found to have significant influence on loan size. The study also found that majority of the loan beneficiaries [70\%] borrowed above $\$ 100,000.00$, the average loan borrowed was $\$ 145,166.67$ at an average interest rate of $15.16 \%$ for 10months. Based on the findings of this study, group borrowings should be encouraged by the farmers. In other to facilitate credit access, crop farmers should form groups or cooperatives because financial institution will prefer lending credit to groups than individuals. It is therefore recommended that government policies can capitalize on the socio-economic variables in this study as veritable tools to encouraging accessibility to MFIs.
\end{abstract}

Keywords-Accessibility, Microfinance Institutions (MFIs), Crop farmers, Credit.

\section{INTRODUCTION}

Access to finance is a necessity when it comes to investing in economic activities so as to ensure production and growth (Nosiro, 2010). However, lack of access to credit facilities is almost universally indicated as a key problem for small and micro enterprises. In most cases, even where credit is available mainly through banks, the entrepreneurs may lack freedom of choice because the banks' lending conditions may force the purchase of heavy, immovable equipment that can serve as collateral for the financial institution. Access to affordable agricultural credit enables farmers, who constitute the majority of the population in most developing countries, to adopt new technology and take advantage of new 
economic opportunities to increase production and income (Gyau and Oduol, 2016).

Despite the recent growth in the microfinance sector, advancing loans and credit to farmers to increase crop production is still a challenge (Tenaw and Islam, 2009). Miller (2011) reports that in order for microfinance organizations to venture into crop agriculture, it is important to understand the context of crop agriculture and their potential role in it. Indeed, agricultural microfinance is not business as usual but requires a different approach from that typically applied in many microfinance organizations. The agricultural sector is characterized by generally much lower returns on capital, slower velocity of capital, higher uncontrolled risks and less understanding of finance and business (Miller, 2011). Also, although it is argued that improved productivity and output levels will be achieved through the introduction of new production technology, credit is a prerequisite to gain access to such technology particularly for the small-scale farmers in Africa with little or no capital of their own. Therefore, microfinance is very critical in increasing crop production. In realization of the enormous potentials of small and medium enterprises as an engine room of economic development and grassroots empowerment, Microfinance are granted to farmers for arable crop cultivation, roots crops cultivation, animal husbandry, poultry farming, fish farming and processing and marketing of agricultural products.

The problem is, there are many obstacles impeding the contribution of microfinance to food and cash crops production. These are the quantity and volume of credit, credit access, high transaction costs, and limited knowledge of Microfinance and inadequate management of information system necessary for Microfinance to achieve positive impacts on agricultural production in the study area. For this reason farmers rely on the costly source of accessing financial services especially through informal sources at higher costs and difficult loan terms and repayment, thus necessitating the research to find out to what extend this institutions have contributed to crop production and find out the factors militating against the achievement of farmers goals in the study area.

In the light of the above, this study tends to answer the following research questions:

i. What are the socioeconomic characteristics of the crop farmers who borrowed from Microfinance and those who did not in the study area? ii. What are the factors determining the accessibility to microfinance

iii. What are the factors affecting the farmers' level of accessibility to microfinance in the study area?

\section{Justification}

Rural financial services is about providing financial servicessecure savings, credit, financial transactions, money transfer services for remittance and insurance-in rural areas. The ability of rural households to make long term investments to ensure time-patterned income flow is shaped by an economy's financial services. Despite the rapid development of financial services, a majority of smallholders around the world especially third world countries remain without access to financial services that they need to improve their livelihoods. Despite the significant demand for financial services in rural areas, institutions offering financial services-such as Banks, credit unions, cooperatives, Microfinance Institutions (MFIs) or insurance companies-are typically reluctant to serve in rural areas due to precarious nature of agricultural production. As a result, the majority of poor households are bereft of financial access to the formal financial system. (Inter-American Development Bank, 2001).

Microfinance does not just have a positive impact on poverty but on agricultural productivity. Despite Nigeria's abundant agricultural resources and oil wealth, poverty is still a challenge in the country (IFAD, 2009). Agricultural productivity is very low in Nigeria. This is because about 90 percent of Nigeria's food is produced by small scale farmers who cultivates small plots of land and depend on rainfall rather than on irrigation. Neglect of rural infrastructure affects the profitability of agricultural production. The neglect of rural roads impedes the marketing of agricultural commodities, prevent farmers from selling their produce at reasonable prices and leads to spoilage. Limited accessibility to credit cuts small scale farmers off from sources of inputs, equipment and new technology and this keeps yields low (IFAD, 2009).

\section{METHODOLOGY}

There are thirty-two (32) Microfinance Banks established in the state (as at the time of this research) but only nineteen (19) have commenced full financial operations. The list of crop farmers (those cultivating rice, maize, yams and other crop for commercial purpose from the three distinctive 
zones) using micro credits was obtained from the nineteen operational Microfinance Banks in the study area. This list represents the sample frame for the micro credit beneficiaries. Ten (10) percent of the beneficiaries from each of the nineteen (19) microfinance bank was estimated and randomly selected. This gave a sample size of one hundred and eighty five (185) microfinance beneficiary farmers. Primary data was used for the study. Primary data was collected through administration of structured questionnaire. A cross-sectional data from a farm survey of crop farmers for 2014 growing season was used. The data collected included demographic information, such as age, educational level, and farm size, amount of credit, crops grown, labour, fertiliser, output levels and years of experience in farming. Also information on marital status, family size, land ownership, income, cost of borrowing, extension contacts (number of visits) and distance to microfinance banks was collected. The analytical tools that were used to achieve the objectives are; descriptive statistics and double hurdle analysis.

\section{Model specifications}

The Double Hurdle model is a parametric generalization of the Probit model, in which the causes and extent of access to credit are determined by two separate stochastic processes given as:

Observed loan size: $\mathrm{Y}=\mathrm{d} . \mathrm{Y}^{* *}$

Loan participation: $\mathrm{W}=\alpha^{\prime} \mathrm{Z}+\mathrm{u}(\mathrm{u} \in \mathrm{N}(0,1))$

$\mathrm{d}=1$ if $\mathrm{W}>0$ and 0 otherwise.

Loan size equation: $\mathrm{Y}^{*}=\beta^{\prime} \mathrm{X}+\mathrm{v}(\mathrm{v} \in \mathrm{N}(0, \delta 2)$

$\mathrm{Y}^{* *}=\mathrm{Y}^{*}$ if $\mathrm{Y}^{*}>0$ and 0 otherwise.

Where

$\mathrm{W}$ is defined whether the households decide to take out credit,

$\mathrm{Y}^{*}$ is latent variable showing farmers' loan amount obtained,

$\mathrm{Y}$ is the observed dependent variables (the amount of money the farmer obtained),

$\mathrm{Z}$ is a vector of variables explaining the credit participation decision,

$\mathrm{X}$ is a vector of variables determining on the credit amount,

$\mathrm{u}$ and $\mathrm{v}$ are the corresponding error terms assumed to be independent and distributed as $\mathrm{u} \in \mathrm{N}(0,1)$ and $\mathrm{v} \in \mathrm{N}(0, \delta 2)$.

This model was solved in one procedure in Strata.The log likelihood of the Double Hurdle model is given as:

$\log (L)=$ $\sum_{0} i n\left[1-\phi\left(z_{i}^{\prime} \propto\right) \phi\left(\frac{x_{i}^{\prime} \beta}{\delta}\right)\right]+\sum_{+} \operatorname{in}\left[\phi\left(z_{i}^{\prime} \propto\right) \frac{1}{\delta} \phi\left(\frac{y-x_{i}^{\prime} \beta}{\delta}\right)\right]$

Where

$\log (\mathrm{L})=$ Accessibility to microfinance (i.e. loan size) (Naira)

$X_{1}=$ age of the farmer (years)

$X_{2}=$ land size (hectares)

$X_{3}=$ ownership of land (1, owned, 0 otherwise)

$X_{4}=$ marital statuses ( 1 if married, 0 otherwise)

$X_{5}=$ farm income of the respondent in 2014(Naira)

$X_{6}=$ cost of borrowing from microfinance (Naira)

$X_{7}=$ education level (Years)

$X_{8}=$ distance/ outreach to microfinance $(\mathrm{Km})$

$X_{9}=$ farming experience (Years)

$X_{10}=$ family size of the respondents (No)

$X_{11}=$ extension contact (No of time)

$\mathrm{Yi}=$ whether farmers access to credit (takes the value of 1 if the farmers take credit, 0 for otherwise).

$\mathrm{Z}$ and $X=$ is the vector of farmers characteristics

$\beta$ and $\alpha=$ is the vector of parameters

$\mu$ and $\varepsilon=$ the error term $\mathrm{N}(0,1)$

Property based determinants are land size, livestock, and other assets. Determinants of borrowing tested in this study include age, educational level, marital status, family size, land ownership, income, cost of borrowing, farming experience, extension contacts (number of visits) and distance to microfinance banks.

\section{RESULTS AND DISCUSSIONS}

\section{Loan characteristics of the farmers}

The loan characteristics of the borrower farmers in the study area showed average loan size of $\$ 145,166.67$. The interest rates charged per year on the borrower farmers was $15.16 \%$, while the average duration of the loans was about 9.69 
months. This implies that shorter loans were given to the borrower farmers for agricultural production.

Table 1 Characteristics of loan received by borrower farmers in the study area

\begin{tabular}{llll}
\hline Variables & Mean & S.D & T-test \\
\hline $\begin{array}{l}\text { Average loan } \\
\text { size( }\end{array}$ & 145166.67 & 53539.26 & $2.71^{* * *}$ \\
$\begin{array}{l}\text { Interest } \\
\text { rates(\%p.a) }\end{array}$ & 15.16 & 7.612 & $1.99 * *$ \\
$\begin{array}{l}\text { Loan } \\
\text { duration(mth) }\end{array}$ & 9.69 & 2.909 & $3.033^{* * *}$ \\
\hline
\end{tabular}

Figure 1 shows that most of the borrower farmers have an average loan of 145,166.67. Majority (70) of the farmers borrowed above $\$ 100,000.00$. Only ten farmers in the sample borrowed more than $\$ 250,000.00$, just five of the farmers borrowed least amounts (below $\$ 50,000.00$ ). Overall, the credit supplied by the formal financial institutions in the study area is rather limited.

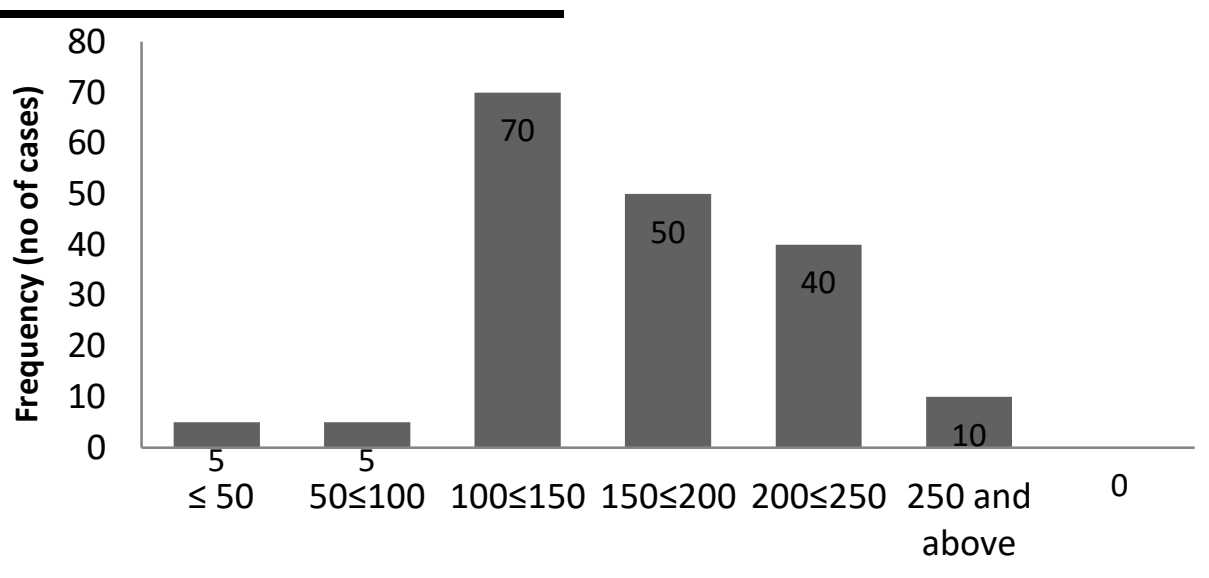

Loan size $\left(\mathbb{A}^{\prime} \mathbf{0 0 0}\right)$

Fig.1 Distribution of Loan amount received by Borrower Farmers

\section{Determinants of Access to Credit by Crop Farmers}

Following the results of the Probit model, access to credit was positively related to the age, farm size, income, and education level of the farmers. The coefficients in table 2 show that the probability of individual farmers' access to credit is positively affected by age, farm size, income, education level of the farmers and negatively related to farming experience, land ownership and household size. These results revealed that variables with positive signs indicate that their higher values increase the chances that the farmers have to access credit and vice versa.

Age and farm size was found to be statistically significant and having positive influence on the probability to access credit. This implies that the chances of the farmers in accessing credit increases with age.
Farm size also plays a crucial role in farming decisions and was considered as an important variable in determining both access to microcredit and size of loan applied for. Households with small farm lands may not need to borrow to finance their production or may only need small loans. However households with large farm lands may need more loans. Furthermore, households with large farm lands may be wealthier or better-off in the community and this can influence their access to credit. Lenders are also more likely to give bigger loans to farmers with large farms compared to those with small farms. This finding is in consistence with Diagne (1999), who noted that farm size was a significant determinant of access to informal credit and the loan size. And also the finding of Okurut (2006), who noted that household with more land are more likely to have an interest 
to expand production and a higher probability of borrowing. Land can also be used as collateral for the loan.

Income of the farmers was found to be a significant factor with a positive influence on the probability to access to microfinance. Household income plays a role in the decision-making of the household regarding whether to seek loan for farming or not. As observed by Dodson (1997), demand for agricultural credit over the short term is influenced by income level and the need to replace capital stock. In rural communities, economic status, such as household income, plays a major role in participation in projects and access to resources. Hence the income of the household is hypothesised to influence both loan access and size. Poorer households may be considered as risky borrowers which can affect their loan access and amount borrowed.

Education level of the farmers was found to be a significant factor with a positive influence on the probability to access to microfinance.The level of education attained by a farmer not only increases his/her farm productivity but also enhances ability to understand and evaluate new production technologies (Ezeh, 2007).

Household size is another important household characteristic which influences many household decisions. Household size was found to have a negative influence on probability to access credit but a significant factor in accessing credit. This implies that household size decreases the probability to access to microcredit. Evidence supported that household size was negatively associated with access to microcredit (Lawal et al, 2009). People with large family size are less likely to accept microcredit (Lawal et al, 2009).However, large family size of 9 and above is most likely to spend more of the microloan in financing consumption and other basic needs as such stands less chance to access microcredit (Akram et al,2008).

Farming experience and land ownership was found to have negative influence on the decision to access to microfinance. This might probably be because of non-acceptability of rural lands by most financial institutions due to its traditional ownership systems.
Table 2 Factors Affecting Access to Credit by Crop Farmers

\begin{tabular}{lccc}
\hline Variables & Coefficients & S.D & Z test \\
\hline Age & 0.0507 & 0.0166 & $3.04^{* * *}$ \\
Farm size & 0.2867 & 0.0403 & $7.11^{* * *}$ \\
Farming & -0.0110 & 0.0156 & -0.71 \\
experience & $1.07 \mathrm{E}-06$ & $6.43 \mathrm{E}-07$ & $1.66^{*}$ \\
Income & 0.2969 & 0.0638 & $4.65^{* * *}$ \\
Education & -0.0842 & 0.0274 & $-3.07^{* * *}$ \\
H/hold size & -0.0378 & 0.1563 & -0.24 \\
Land & -3.1331 & 0.7013 & $-4.47^{* * *}$ \\
ownership & & & \\
Constant & & & \\
\hline Log & & & \\
\hline
\end{tabular}

Log likelihood $\quad-192.4287$

$\operatorname{LR} \operatorname{chi}^{2}(7)$

114.21

Prob $\mathrm{chi}^{2}$

0.0000

Pseudo $\mathrm{R}^{2}$

0.2288

\section{Determinants of loan amount/size}

Following the results in table 3 , the determinants of the loan amount/size as calculated in the double hurdle models showed that loan amount/size has positive coefficient and was related to marital status, farm size, education, cost of borrowing, farming experience, house hold size, distance to the microfinance bank and extension contacts. The coefficients also showed the probability of borrower farmer loan size is negatively related to age of the borrower and income level. Age was found to be statistically significant and having negative influence on loan amount/size.The negative coefficients of age imply that the chances of the farmers in accessing credit and its size decreases with age. It also means that old age tends to reduce the probability of accessing microfinance credit and loan size. It infers that younger farmers stand better chance than older farmers in accessing microfinance. This is however in agreement with Adeyemi (2008) who showed that older farmers stand less chance of accessing microfinance.This result is also consistent with the findings of Sebopetji and Belete (2009).

Farm size was found to be positively correlated with loan size and was statistically significant at $1 \%$ level. This finding was in consistence with Diagne (1999), who noted that farm size was a significant determinant of access to informal credit and the loan size. Land ownership had a positive influence amount borrowed but not statistically significant in 
the amount/size of the loan. This is so because land in rural areas especially land held under custom, generally lacks formal documentation. Mobuogwu (2013) noted that since such lands lack documentation, securing loan with such (as collateral) becomes problematic, as banking institutions require titles for land to be eligible as collateral. In the same vein, it was noted that under many customs, rural dwellers have only possessory rights to the land they occupy. As a result, the consent of the family or village head is needed to transact with or alienate such land. Moreover, under many cultures in Nigeria, women are excluded from inheritance, despite women representing 50 percent of the agricultural labor force and farming constituting the principal business in rural areas. As such, 50 percent of the agricultural labor force is often deprived of the assets needed to obtain loans (FOA, 2011).

Marital status has a positive influence on loan amount/size and was found to be statistically significant at $1 \%$ level. This could be as a result and perception that marriage confers responsibility and some degree of trustworthiness which could be a strong weapon particularly when it comes to loan repayment.

Cost of borrowing from the microfinance had a positive influence on the loan size and was also significantly related to the loan amount. This implies that the more the volume of the loan acquired by the borrower the high the cost of obtaining it. This also is a determinant of loan size.

Education was found to be statistically significant at 5\% level and also having a positive influence on the loan amount/size. The implication is that it may be deliberate policy of MFIs to issue microcredit to literate clientele. Education is perhaps supposed to impact positively on farmers' access to credit and other resources and even in their usage. Adereti (2005) confirms that education is an essential tool in accessing and using farm resources efficiently.

Years of farming experience of the borrower farmers was noted to be positively and significantly related to loan amount/size. The years of farming experience of the household head is believed to influence both access to loan and the size of loan. This is because older farmers with years of farming experience are expected to be knowledgeable about farming and the various sources of credit. They are also expected to have better credit management skills and credibility with lenders (Anang et.al,2015).

Distance to the microfinance bank has a positive influence on the loan amount. In the findings of Pedrosa and Do
(2008) noted that long distances between clients and microfinance offices limits access to basic financial services and thus a major barrier to development.

Household size was found to have a positive influence on loan size. Access to microcredit and the amount of loan borrowed are hypothesised to be influenced by the size of the farming household as it determines the household labour supply which is important for agricultural production. Households with limited labour supply may need to borrow to augment their labour supply while households with excess labour may not face such liquidity constraints. Household size can therefore ease the liquidity constraints of the household, thus influencing the decision to borrow as well as the loan amount.

Extension contacts were found to have a positive influence on the loan amount/size but not statistically significant in the amount/size of the loan acquired. This indicates that extension service delivery enhances accessibility to microcredit. The result is expected because extension agents are important source of information for many rural farmers. Extension agents also help to link farmers' groups to credit sources. Thus extension contact is expected to positively impact access to microcredit. The result agrees with Sanusi and Adedeji (2010) who reported a positively significant relationship between extension contact and access to formal credit in Rwanda. Efforts to improve access to agricultural microcredit to smallholder farmers must therefore take into consideration the improvement of extension service delivery to farmers.

Table 3 Determinant of Loan Size

\begin{tabular}{lll}
\hline Loan size & Co-efficient & T value \\
\hline Age & $-1032.382(463.473)$ & $-2.23^{* * *}$ \\
Farm size & $3669.716(947.855)$ & $3.87^{* * *}$ \\
Land & $7.144(4313.064)$ & 0.001 \\
ownership & & \\
Marital status & $44985.230(13137.070)$ & $3.42^{* * *}$ \\
Income & & \\
Cost & & \\
borrowing & $-0.020(0.127)$ & -1.63 \\
Education & $4.407(0.175)$ & $25.07 * * *$ \\
$\begin{array}{l}\text { Distance } \\
\text { bank }\end{array}$ & $3806.714(1871.141)$ & $2.03 * *$ \\
Farming & & \\
experience & $199.013(154.433)$ & 1.29 \\
\hline
\end{tabular}




\begin{tabular}{lll}
\hline $\begin{array}{l}\text { Household size } \\
\text { Extension } \\
\text { contact }\end{array}$ & $792.147(386.378)$ & $2.05^{* *}$ \\
-Constant & $611.824(787.543)$ & 0.78 \\
& & \\
& $1133.284(1020.318)$ & 1.11 \\
& $-26994.89(25997.89)$ & -1.04
\end{tabular}

Figures outside the parentheses_co-efficient, figures inside the parentheses_standard deviation, ***Significant at $1 \%$ ** Significant at $5 \%$

\section{CONCLUSION}

It was observed from the study that age, farm size, income, education level and household size were factors that significantly affect access to credit. And equally, age, farm size, marital status, cost of borrowing, education level and farming experience had a significant influence on the loan size. The findings of the study indicates that there is high interest rates charged by the microfinance and the volume of loans availed to the farmers was too low for any meaningful crop production. The distance to most of these microfinance banks, coupled with lot of bureaucracy the farmers undergoes before obtaining loan and untimely disbursement makes the farmer want to go without the loan and sometimes divert it to other use other than crop production.

Based on the findings of the study and conclusion drawn, these policy recommendations are made. Banking policies for agricultural credit are still business oriented rather than directed towards development. So, it is imperative on the part of Federal Government to outline some policies and programmes aimed at larger national interest rather than individual and personal gains. Thus, the Central Bank of Nigeria (CBN) through credit policies should make efforts to simplify the borrowing procedure in the terms of time-lag, acceptance of security, documentation and disbursement of loan. On the other hand, credit facility by microfinance banks should be provided on time, otherwise the delay in the completion procedure for taking loans will occur and the farmers will not get maximum profit regarding their plans. Finally, acquisition and recovery process for credit should be simple to give benefits to maximum number of farmers.

\section{REFERENCES}

[1] Adeyemi, K. S. (2008). Institutional reforms for efficient microfinance operations in Nigeria.Central Bank of Nigeria Bullion, 32(1), 26-34.

[2] Adereti F. O (2005). Rural Womens' Access to and control over Productive Resources; Implications for Poverty Alleviation among Osun State Rural Women, Nigeria. Journal of Human Ecology, 18(3):225-230

[3] Akram, W.,Z. Hussain,H. Sabir, and M. Hussain (2008). Impact of Agricultural Credit ongrowth and poverty in Pakistan (Time Series Analysis). European Journal of Scientific Research, 23(2), 243-251.

[4] Anang, B. A, T. Sipiläinen, S. Bäckman and J. Kola (2015). Factors influencing smallholder farmers' access to agricultural microcredit in Northern Ghana vol. 10(24), pp.2460-2469, 11 june,2015. DOI: 10.5897AJAR ISSN 1991637X http://www.academicjournals.org/AJAR

[5] Diagne, Aliou (1999). "Determinants of household access to and participation in formal and informal credit markets in Malawi." Food Consumption and Nutrition Division, Discussion Paper No. 67.

[6] Dodson C. B (1997). Changing Agricultural Institutions and Markets. The Farm Credit Outlook Mimeo pp. 1-25.

[7] Ezeh C.I (2007).Impact of Selected Rural Development Programme on Poverty Alleviation in Ikwuano LGA, Abia State, Nigeria. African Journal of Food Agriculture, Nutrition and Development, 7(5).ISSN 1684-5374

[8] Food And Agricultural Organisation.(2011). The State of Food and Agriculture 2010-2011, FAO Rome,Italy. http://www.fao.org/docrep/013/i2050e/i2050.pdf.

[9] Gyau A, Mbugua M, and Oduol J.(2016). Determinants of Participation and Intensity of Participation in collective action: Evidence from smallholder avocado farmers in Kenya. Journal on Chain and Network Science. Wageningen . 16(2):147-156

[10] Inter-American Development Bank (2001). Rural Finance Strategy, Sustainable Development Sector Strategy and Policy Papers series, Washington, DC.

[11] International Fund for Agricultural Development (2009). Enabling Poor Rural People to Overcome Poverty in Nigeria. IFAD via Paolo di Dono. Rome, Italy.

[12] Lawal ,J.O., B.T Omonona,O.I.Y Ajani and O.A Oni (2009). Effects of social capital on credit access among cocoa farming households in Osun State,Nigeria. Agricultural Journal,4 (4)184-191.

[13] Nosiru, M.O(2010).Microcredits and Agricultural Productivity in Ogun State, Nigeria. World Journal of Agricultural Science,6(3): 290-296.IDOSI Publications.

[14] Miller, C (2011). Agricultural Value Chain Finance Strategy and Design. Technical Note.Rome: Food and Agriculture Organization of the United Nations.

[15] Mobuogwu Maureen (2013). Rural Land and Credit access in Nigeria. Focus on land in Africa. World Resources Institute. 
[16] Okurut, Francis Nathan (2006). "Access to credit by the poor in South Africa: Evidence from Household Survey Data 1995 and 2000." Stellenbosch economic working papers: 13/2006.

[17] Pedrosa, Jose and Quy-Toan Do (2008). How does geographic distance affect credit marketaccess in Niger? Policy Research Working Paper Series 4772. The World Bank.

[18] Sanusi, W. A and Adedeji, I. A. (2010). "A Probit Analysis of Accessibility of Small-ScaleFarmers to Formal Source of Credit in Ogbomosho Zone, Oyo State, Nigeria." Agricultural Tropica et Subtropica 43 (1): 49-53.

[19] Sebopetji T.O and Belete, A. (2009). An Application of Probit Analysis to Factors Affecting Small-Scale Farmers' Decision to take Credit: A Case Study of Greater Letabo Local Municipality in South Africa. Africa Journal of Agricultural Research, 4(8):718-723.

[20] Tenaw, S.K.M., Islam, Z and Parviainen, T (2009). Effects of Land Tenure and Property rightson agricultural productivity in Ethiopia, Namibia and Bangladesh. University of Helsinki Department of Economics and Management Discussion Papers no 33 Helsinki 2009. 